\title{
Feasibility of Pressurized Irrigation in Canal Command Area of Samrat Ashok Sagar Project a Case Study
}

\author{
Shiv Singh Basediya*, S.K. Pyasi, R.N. Shrivastava and S.K. Sharma \\ Department of Soil and Water Engineering, J.N. K. V. V., Jabalpur, India \\ *Corresponding author
}

\section{Keywords \\ Canal irrigation, Canal command area, Water productivity, \\ Pressurized irrigation \\ Article Info \\ Accepted: \\ 15 January 2018 \\ Available Online: \\ 10 February 2018}

\section{A B S T R A C T}

A huge amount has been invested on irrigation project but these project are not achieving the target most of these hence the very low water productivity ranging wet been $0.52-0.72$ $\mathrm{kg} / \mathrm{m}^{3}$ and 30-50 irrigation efficiency lining of the canal and transpiring the management to WUA also could not result in this scenario. Application pressurized irrigation in place of surface irrigation since to be a solution. feasibility of pressurized irrigation system the characters like awareness of farmers, technical knowledge, attitude, adoption of willingness, purchasing capacity and of farmers were consider and analyzed through Chi square test and it was found that type of farmers and there awareness, technical knowledge, attitude, adoption of willingness and purchasing capacity of farmers dependent on each other that is the large farmer could have the different awareness, technical knowledge, attitude, willingness of adoption and purchasing capacity than marginal, small and medium farmers. On the basis of this it is concluded that pressurized irrigation system is feasible for RBC command area. Result of these trails so enhancement of water productivity in the range flood to border $(0.67-0.74)$, flood to sprinkler $(0.67-0.1 .27)$ and border to sprinkler (0.74-1.27).

\section{Introduction}

In India, most of the irrigation networks are unlined and huge amount of the irrigation water is lost in main canal, distributary, minors and field channels. The land area under irrigation has prolonged from 22.6 million hectares in 1950 to 90 million hectares in 2000 , with $52 \%$ area being irrigated by surface water through canal network. In India total geographic area $329 \mathrm{M}$ ha, currently the gross irrigated area is $87 \mathrm{M}$ ha, the net irrigated area is $65.3 \mathrm{M}$ ha, gross cropped area is $195 \mathrm{M}$ ha and net sown area is $141 \mathrm{M}$ ha (agricoop annual report GOI, 2014-2015). Navalwala (1991) found that about $71 \%$ of the irrigation water is lost in the whole process of its conveyance from head works and application in the field. The breakups of the losses are main and branch canal (15\%), distributaries $(7 \%)$, water courses $(22 \%)$ and field losses of $27 \%$. Zardari and Cordery (2009) found that in warabandi irrigation system of Indus basin of Pakistan, almost half the irrigation water delivered from the reservoir does not give direct benefits to the farmers. Crop demand for irrigation water under warabandi principles did not match the amount of canal water 
allocated to farmers. Irrigation water availability ranged between 0.82 and 1.92 $\mathrm{mm}$ /day only in the watercourse where the study was carried out. There was wide variation in canal water allocations for head, middle, and tail end farmers. The actual amount of water received by tail end farmers was small as about $25 \%$ of the allocated water share was lost in unlined water courses. Hence, there is a need to improve irrigation efficiency of canal irrigation system for enhancing productivity as well as ensuring equity among farmers of different segments.

Nema and Shrivastava (2012) studies Pressurized Irrigation in Canal Command Area Reported that of RABS Project only 105 ha, out of 210 ha was receiving proper irrigation and rest of the area was almost unirrigated. After intervention of sprinkler irrigation, area increased by 90 ha towards the tail end and efficiency and water productivity increased as compared to head reach. Rathod et al., (2013) Study they are left with no alternatives but to adopt a modern irrigation technology which saves water, double the area under irrigation, improve yields and quality as well as saves on labour, energy and crop production costs.

Shifting from surface irrigation to pressurized irrigation system requires changing the supply of water from on-off mode to continuous, reduction of turbidity to desirable level and modifying system to provide surface irrigation to rice crop in monsoon and different types of pressurized irrigation to suit different crops of the command in post monsoon season. The technical and economic feasibility of these interventions require studying the real field conditions. With this in view, a pilotstudy on one outlet of a minor irrigation system was conducted to convert a 5 ha area from surface irrigated to hybrid pressurized irrigated system and evaluate its technical and economic feasibility (Shrivastava et al., 2010).

\section{Materials and Methods}

The plateau areas of eastern India are characterized by high rainfall ranging between 800 to $1,600 \mathrm{~mm}$. The mean monthly distribution of rainfall and their standard deviation of the region are shown in Figure 1. Bulk of the rainfall occurs during the monsoon period of June to September (90\% of total rainfall). Maximum average rainfall occurs in the month of July $(456.74 \mathrm{~mm})$ followed by August $(367.75 \mathrm{~mm})$ and September (138.16 $\mathrm{mm})$ respectively. The standard deviation values varies form $111 \mathrm{~mm}$ to $199.2 \mathrm{~mm}$ during the monsoon period of June to October and $4.0 \mathrm{~mm}$ to $42.8 \mathrm{~mm}$ during the nonmonsoon period of November to May. But the coefficient of variation values varies from $16101.80 \%$ to $12312.24 \%$ during the monsoon months and $16.07 \%$ to $1827.70 \%$ in nonmonsoon months. So, even though standard deviations are higher in the monsoon months, the deviations with respect to mean in the above months are lower.

As significant rainfall occurs during monsoon season (June-September), only rice crop can be grown in medium and low lands, which form major canal command area. The canal water carries a heavy silt load especially during monsoon, which has to be taken care of before this water is used for pressurized irrigation. The land holdings in the command of an outlet are small with large number of owners of varied socio economic background and therefore the command area has diversified cropping pattern especially during post monsoon season, each requiring different irrigation method. A canal-based pressurized irrigation system should satisfy following conditions:

\section{Study area}

The study has been under taken in the command area of right bank canal of Samrat 
Ashok Sagar Irrigation Project located in Vidisha district, Madhya Pradesh (India) (Figure 3). The gross command area of the Smrat Ashok Sagar (SAS) project is 37419 ha, cultural command area is 32292 ha and canal irrigated area is 30151 ha. The total irrigated area of SAS project is about 44000 ha, including irrigation through other sources. 2141 ha area out of total irrigated area is being irrigated through pumping from canals as water is not reaching there by gravity flow. Similarly 7091 ha area of out of command and 4617 ha of submerged area is also irrigated through pumping from canal. The cultural command area of Right Bank Canal is 7261 ha and irrigated area of RBC command is 7067 ha. Out of this 194 ha area is being irrigated through pumping from canals as water is not reaching through gravity. Similarly 2242 ha area of out of RBC commands and 1424 ha of submerged area is also being irrigated through pumping from canal. The supply of canal water is stopped in the month of February to meet to Increasing demand of drinking water for Vidisha Township. So in peak maturity period of crops farmers do not get water. The tail end farmers do not get water during supply period because of seepage losses, over irrigation and poor maintenance of system. This all result in low water productivity, "Pressurized irrigation in command area" is emerging as a solution of these problems as reported by shrivastava et al., (2006), Nema and shrivastava (2012), Rathod and Shah (2013).The maximum area of RBC command is not receiving water from canal and conflict situation occurs very often during rabi season.

\section{Results and Discussion}

\section{Feasibility of pressurized irrigation}

Feasibility of pressurized irrigation technically was judged through an interview schedule and score matrix as suggested and adopted by R.C. Shrivastsva at al. 2010. These are five characters like awareness of farmers, technical knowledge, attitude, adoption of willingness, purchasing capacity. Table 1 gives about the contingency table of $(4 \times 4)$ type farmers and their awareness categorizing marginal, small, medium large farmers and nil, poor, medium high respectively.

The calculated Chi square test value is 20.72 which are larger than the tabulated value 16.919 at 9 d.f. Thus the null hypothesis was rejected and it was concluded that the type of farmers and their awareness dependent on each other that is the large farmer could have the different awareness than marginal, small and medium farmers. The null hypothesis was postulated as below.

H0: Type of farmers and their awareness are independent.

H1: Type of farmers and their awareness are dependent.

Gives about the contingency table of $(4 \times 4)$ type farmers and their attitude categorizing marginal, small, medium large farmers and nil, poor, medium high respectively. The Chi square test of independent of attributes was the applied per the contingency table 2 .

The calculated Chi square test value is 27.46 which are larger than the tabulated Chi square value 9 d.f. is 16.919 . Thus the null hypothesis was rejected and it was concluded that the type of farmers and their attitude dependent on each other that is the large farmer could have the different attitude than marginal, small and medium farmers. The null hypothesis was postulated as below.

H0: Type of farmers and their Technical knowledge are independent.

H1: Type of farmers and their Technical knowledge are dependent. 
Table.1 Awareness of farmer in command area

\begin{tabular}{|c|c|c|c|c|c|c|c|c|c|c|c|c|c|c|}
\hline $\begin{array}{l}\text { Farmers } \\
\text { Category }\end{array}$ & $\begin{array}{l}\text { Nil } \\
(\mathrm{Oi}) *\end{array}$ & $\begin{array}{l}\text { (Ei) } \\
* *\end{array}$ & $\frac{(\mathrm{Oi}-\mathrm{Ei})^{2}}{\mathrm{Ei}}$ & $\begin{array}{l}\text { Poor } \\
\text { (Oi) }\end{array}$ & Ei & $\frac{(\mathrm{O}-\mathrm{Ei})^{2}}{\mathrm{Ei}}$ & $\begin{array}{l}\text { Medium } \\
\text { (Oi) }\end{array}$ & Ei & $\frac{(\mathrm{O}-\mathrm{Ei})^{2}}{\mathrm{Ei}}$ & $\begin{array}{l}\text { High } \\
\text { (Oi) }\end{array}$ & Ei & $\frac{(\mathrm{Oi}-\mathrm{Ei})^{2}}{\mathrm{Ei}}$ & $\begin{array}{l}\text { Total } \\
\text { (Oi) }\end{array}$ & $\begin{array}{l}\text { Total } \\
\frac{(\mathrm{Oi}-\mathrm{Ei})^{2}}{\mathrm{Ei}}\end{array}$ \\
\hline Marginal & 12 & 6.2 & 5.29 & 11 & 9 & 0.33 & 12 & 14 & 0.22 & 10 & 16 & 2.10 & 45 & 7.94 \\
\hline Small & 8 & 6.2 & 0.49 & 13 & 9 & 1.52 & 12 & 13 & 0.22 & 12 & 16 & 0.89 & 45 & 3.13 \\
\hline Medium & 3 & 6.2 & 1.69 & 7 & 9 & 0.55 & 15 & 13 & 0.11 & 20 & 16 & 1.15 & 45 & 3.50 \\
\hline Large & 2 & 6.2 & 2.89 & 6 & 9 & 1.14 & 16 & 13 & 0.37 & 21 & 16 & 1.75 & 45 & 6.15 \\
\hline Total & 25 & 24.8 & 10.36 & 37 & 36 & 3.54 & 55 & 53 & 0.93 & 63 & 64 & 5.89 & 180 & 20.72 \\
\hline
\end{tabular}

Where * Observed value, ** Expected value

Table.2 Technical knowledge of farmer in command area

\begin{tabular}{|c|c|c|c|c|c|c|c|c|c|c|c|c|c|c|}
\hline $\begin{array}{l}\text { Farmers } \\
\text { Category }\end{array}$ & $\begin{array}{l}\text { Nil } \\
(\mathbf{O i} \\
)^{*}\end{array}$ & $\begin{array}{l}\text { (Ei) } \\
* *\end{array}$ & $\frac{(\mathrm{O} i-\mathrm{Ei})^{2}}{\mathrm{Ei}}$ & $\begin{array}{l}\text { Poo } \\
\mathbf{r} \\
(\mathrm{Oi})\end{array}$ & Ei & $\frac{(\mathrm{O} \mathrm{i}-\mathrm{Ei})^{2}}{\mathrm{Ei}}$ & $\begin{array}{l}\text { Med } \\
\text { ium } \\
(\mathrm{Oi})\end{array}$ & Ei & $\frac{(\mathrm{O} i-\mathrm{Ei})^{2}}{\mathrm{Ei}}$ & $\begin{array}{l}\text { Hig } \\
\text { h } \\
\text { (Oi) }\end{array}$ & Ei & $\frac{(\mathrm{O} \text { i-Ei })^{2}}{\mathrm{Ei}}$ & $\begin{array}{l}\text { Tot } \\
\text { al } \\
\text { (Oi) }\end{array}$ & $\begin{array}{l}\text { Total } \\
\left(\frac{O \text { i-Ei })^{2}}{\text { Ei }}\right.\end{array}$ \\
\hline Marginal & 17 & 10.5 & 4.02 & 12 & 10.5 & 0.21 & 9 & 11.25 & 0.45 & 7 & 12.7 & 2.59 & 45 & 7.28 \\
\hline Small & 15 & 10.5 & 1.93 & 14 & 10.5 & 1.17 & 8 & 11.25 & 0.94 & 8 & 12.7 & 1.77 & 45 & 5.80 \\
\hline Medium & 7 & 10.5 & 1.17 & 9 & 10.5 & 0.21 & 13 & 11.25 & 0.27 & 16 & 12.7 & 0.83 & 45 & 2.48 \\
\hline Large & 3 & 10.5 & 5.36 & 7 & 10.5 & 1.17 & 15 & 11.25 & 1.25 & 20 & 12.7 & 4.12 & 45 & 11.90 \\
\hline Total & 42 & 42 & 12.48 & 42 & 42 & 2.76 & 45 & 45 & 2.91 & 51 & 51 & 9.31 & 180 & 27.46 \\
\hline
\end{tabular}

Where * Observed value, ** Expected value

Table.3 Attitude of farmer in command area

\begin{tabular}{|c|c|c|c|c|c|c|c|c|c|c|c|c|c|c|}
\hline $\begin{array}{l}\text { Farmers } \\
\text { Category }\end{array}$ & $\begin{array}{l}\text { Nil } \\
(\mathrm{Oi} \\
)^{*}\end{array}$ & $\begin{array}{l}\text { (Ei) } \\
* * *\end{array}$ & $\frac{(\mathrm{Oi}-\mathrm{Ei})^{2}}{\mathrm{Ei}}$ & $\begin{array}{l}\text { Poor } \\
\text { (Oi) }\end{array}$ & Ei & $\frac{(\mathrm{Oi}-\mathrm{Ei})^{2}}{\mathrm{Ei}}$ & $\begin{array}{l}\text { Med } \\
\text { ium } \\
(\mathrm{Oi})\end{array}$ & Ei & $\frac{(\mathrm{Oi}-\mathrm{Ei})^{2}}{\mathrm{Ei}}$ & $\begin{array}{l}\text { Hig } \\
\text { h } \\
\text { (Oi) }\end{array}$ & Ei & $\frac{(\mathrm{Oi}-\mathrm{Ei})^{2}}{\mathrm{Ei}}$ & $\begin{array}{l}\text { Tota } \\
1 \\
(\mathrm{Oi})\end{array}$ & $\begin{array}{l}\text { Total } \\
\frac{(\mathrm{O} \text { i-Ei })^{2}}{\mathrm{Ei}}\end{array}$ \\
\hline Marginal & 14 & 8 & 4.50 & 16 & 13.5 & 0.46 & 9 & 12.5 & 0.98 & 6 & 11 & 2.27 & 45 & 8.22 \\
\hline Small & 10 & 8 & 0.50 & 17 & 13.5 & 0.91 & 11 & 12.5 & 0.18 & 7 & 11 & 1.45 & 45 & 3.04 \\
\hline Medium & 6 & 8 & 0.50 & 12 & 13.5 & 0.17 & 15 & 12.5 & 0.50 & 12 & 11 & 0.09 & 45 & 1.26 \\
\hline Large & 2 & 8 & 4.50 & 9 & 13.5 & 1.50 & 15 & 12.5 & 0.50 & 19 & 11 & 5.82 & 45 & 12.32 \\
\hline Total & 32 & 32 & 10.00 & 54 & 54 & 3.04 & 50 & 50 & 2.16 & 44 & 44 & 9.64 & 180 & 24.83 \\
\hline
\end{tabular}

Table.4 Purchasing capacity of farmer in command area

\begin{tabular}{|c|c|c|c|c|c|c|c|c|c|c|c|c|c|c|}
\hline $\begin{array}{l}\text { Farmers } \\
\text { Category }\end{array}$ & $\begin{array}{l}\text { Nil } \\
(\mathrm{Oi} \\
)^{*}\end{array}$ & $\begin{array}{l}\text { (Ei) } \\
* *\end{array}$ & $\frac{(\mathrm{Oi}-\mathrm{Ei})^{2}}{\mathrm{Ei}}$ & $\begin{array}{l}\text { Poo } \\
\mathbf{r} \\
(\mathrm{Oi})\end{array}$ & Ei & $\frac{(\mathrm{Oi}-\mathrm{Ei})^{2}}{\mathrm{Ei}}$ & $\begin{array}{l}\text { Med } \\
\text { ium } \\
(\mathrm{Oi})\end{array}$ & Ei & $\frac{(\mathrm{O}-\mathrm{Ei})^{2}}{\mathrm{Ei}}$ & $\begin{array}{l}\text { Hig } \\
\text { h } \\
\text { (Oi) }\end{array}$ & Ei & $\frac{(\mathrm{Oi}-\mathrm{Ei})^{2}}{\mathrm{Ei}}$ & $\begin{array}{l}\text { Tot } \\
\text { al } \\
\text { (Oi) }\end{array}$ & $\begin{array}{l}\text { Total } \\
(\text { Oi-Ei })^{2} \\
\text { Ei }\end{array}$ \\
\hline Marginal & 17 & 10.25 & 4.45 & 12 & 11.25 & 0.05 & 9 & 13.25 & 1.36 & 7 & 10.2 & 1.03 & 45 & 6.89 \\
\hline Small & 12 & 10.25 & 0.30 & 11 & 11.25 & 0.01 & 16 & 13.25 & 0.57 & 6 & 10.2 & 1.76 & 45 & 2.64 \\
\hline Medium & 9 & 10.25 & 0.15 & 14 & 11.25 & 0.67 & 13 & 13.25 & 0.00 & 9 & 10.2 & 0.15 & 45 & 0.98 \\
\hline Large & 3 & 10.25 & 5.13 & 8 & 11.25 & 0.94 & 15 & 13.25 & 0.23 & 19 & 10.2 & 7.47 & 45 & 13.77 \\
\hline Total & 41 & 41 & 10.02 & 45 & 45 & 1.67 & 53 & 53 & 2.17 & 41 & 41 & 10.41 & 180 & 24.28 \\
\hline
\end{tabular}

Table.5 Willingness of adoption of farmer in command area

\begin{tabular}{|l|r|r|r|}
\hline $\begin{array}{l}\text { Farmers } \\
\text { Category }\end{array}$ & \multicolumn{1}{l|}{$\begin{array}{l}\text { Nil } \\
(\mathrm{Oi}) *\end{array}$} & $\begin{array}{l}\text { (Ei) } \\
* * *\end{array}$ & \multicolumn{1}{l|}{\begin{tabular}{l} 
(Oi-Ei $)^{2}$ \\
\hline Marginal
\end{tabular}} \\
\hline Small & 17 & 10.5 & 4.02 \\
\hline Medium & 8 & 10.5 & 1.93 \\
\hline Large & 2 & 10.5 & 0.60 \\
\hline Total & $\mathbf{4 2}$ & $\mathbf{4 2}$ & $\mathbf{1 3 . 4 3}$ \\
\hline
\end{tabular}

\begin{tabular}{|r|r|}
\hline \multicolumn{1}{|l|}{$\begin{array}{l}\text { Poor } \\
\text { (Oi) }\end{array}$} & \multicolumn{1}{l|}{ Ei } \\
\hline 16 & 12.25 \\
\hline 14 & 12.25 \\
\hline 13 & 12.25 \\
\hline 6 & 12.25 \\
\hline 49 & 49 \\
\hline
\end{tabular}

\begin{tabular}{|r|r|r|}
\multicolumn{1}{|l|}{$(\mathbf{O i} \text {-Ei })^{2}$} & \multicolumn{2}{l|}{$\begin{array}{l}\text { Medium } \\
\text { (Oi) }\end{array}$} \\
\hline 1.15 & 8 & 12.25 \\
\hline 0.25 & 11 & 12.25 \\
\hline 0.05 & 13 & 12.25 \\
\hline 3.19 & 17 & 12.25 \\
\hline $\mathbf{4 . 6 3}$ & 49 & 49 \\
\hline
\end{tabular}

\begin{tabular}{|r|}
\hline \multicolumn{1}{|c|}{ (Oi-Ei $)^{2}$} \\
\hline 1.47 \\
\hline 0.13 \\
\hline 0.05 \\
\hline 1.84 \\
\hline $\mathbf{3 . 4 9 0}$ \\
\hline
\end{tabular}

\begin{tabular}{|c|c|}
\hline $\begin{array}{l}\text { High } \\
\text { (Oi) }\end{array}$ & Ei \\
\hline 4 & 10 \\
\hline 5 & 10 \\
\hline 11 & 10 \\
\hline 20 & 10 \\
\hline 40 & 40 \\
\hline
\end{tabular}

\begin{tabular}{|r|}
\hline \multicolumn{1}{|c|}{ (Oi-Ei $)^{2}$} \\
\hline 3.60 \\
\hline 2.50 \\
\hline 0.10 \\
\hline 10.00 \\
\hline $\mathbf{1 6 . 2 0}$ \\
\hline
\end{tabular}

\begin{tabular}{|r|r|}
\multicolumn{1}{|l|}{$\begin{array}{l}\text { Total } \\
\text { (Oi) }\end{array}$} & $\begin{array}{l}\text { Total } \\
(\mathrm{Oi}-\mathrm{Ei})^{2}\end{array}$ \\
\hline 45 & $\mathbf{1 0 . 2 5}$ \\
\hline 45 & 4.81 \\
\hline 45 & 0.79 \\
\hline 45 & 21.91 \\
\hline 180 & 37.75 \\
\hline
\end{tabular}


Fig.1 Mean monthly rainfall of the study area with standard deviation bars

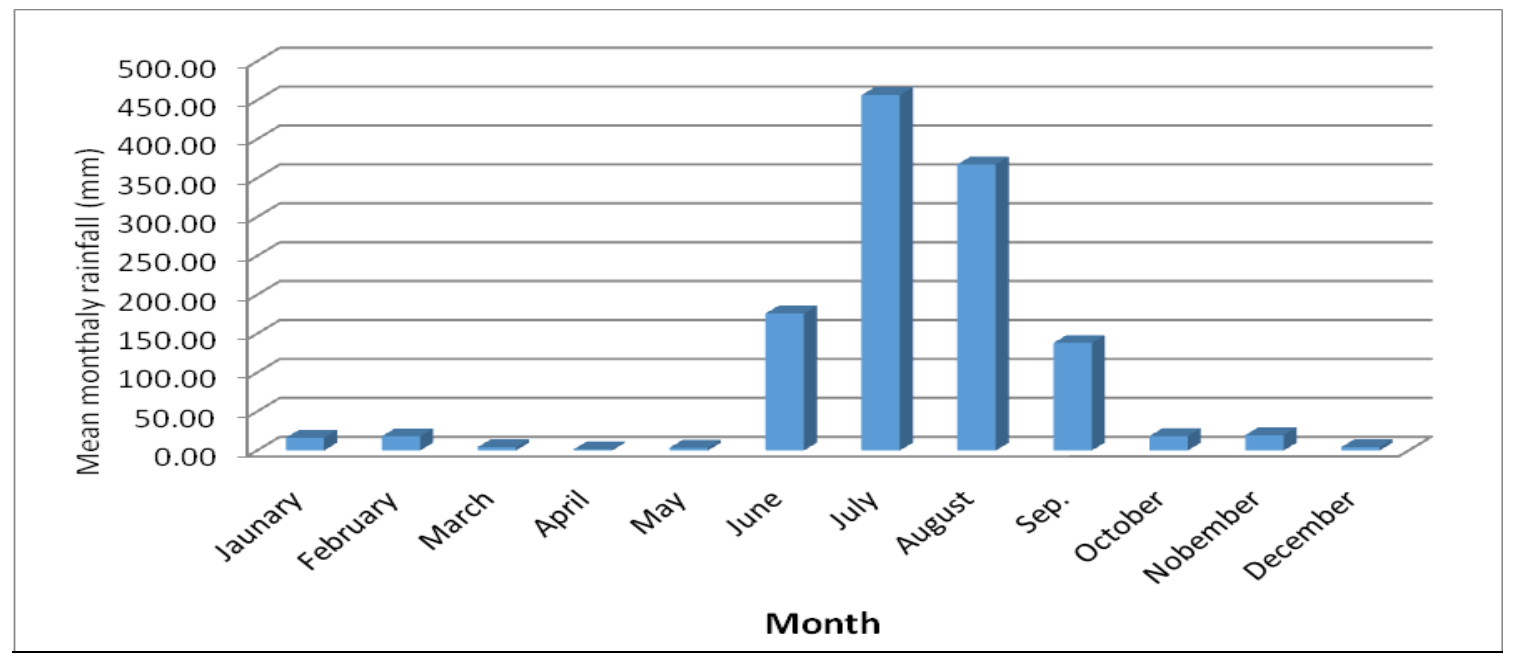

Fig.2 Water productivity of different irrigation method

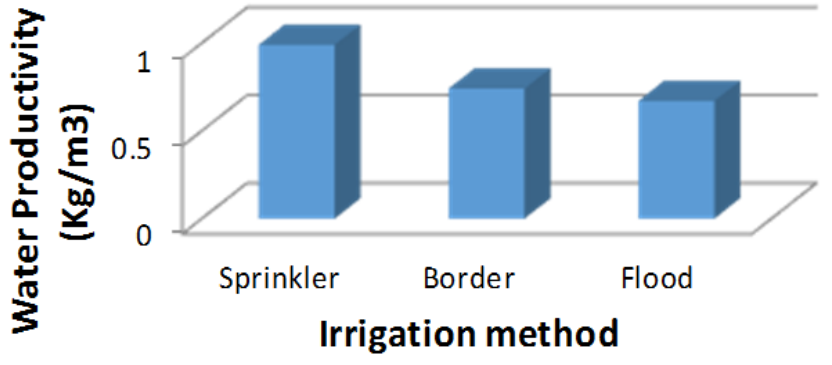

Average Water Productivity, $\mathrm{Kg} / \mathrm{m} 3$

Fig.3 Map of the stody area

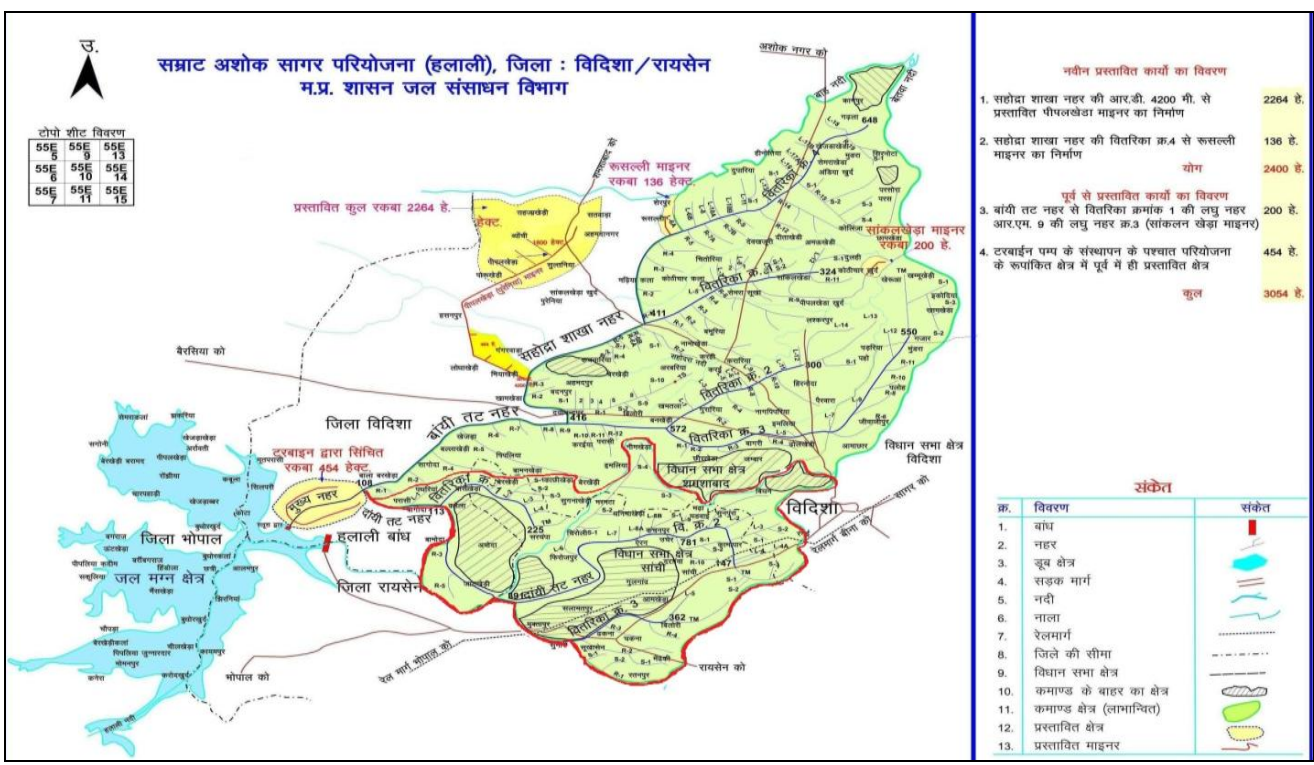


Table 3 denoted the calculated Chi square test value is 24.83 which is larger than the tabulated Chi square value 9 d.f. is 16.919 . Thus the null hypothesis was rejected and it was concluded that the type of farmers and their attitude dependent on each other. The null hypothesis was postulated as, H0: Type of farmers and their attitude are independent, H1: Type of farmers and their attitude are dependent. The Chi square test of independent of attributes was the applied per the contingency table 4 . The calculated Chi square test value is 24.28 , which is larger than the tabulated Chi square value 9 d.f. is 16.919. Thus the null hypothesis was rejected and it was concluded that the type of farmers and their Purchasing capacity dependent on each other that is the large farmer could have the different Purchasing capacity than marginal, small and medium farmers. The null hypothesis was postulated as below.

H0: Type of farmers and their Purchasing capacity are independent.

H1: Type of farmers and their Purchasing capacity are dependent.

The Chi square test of independent of attributes was the applied per the contingency table 5. The calculated Chi square test value is 37.75, which is larger than the tabulated Chi square value 9 d.f. is 16.919. Thus the null hypothesis was rejected and it was concluded that the type of farmers and their Willingness of adoption dependent on each other that is the large farmer could have the different Willingness of adoption than marginal, small and medium farmers. The null hypothesis was postulated as below.

H0: Type of farmers and their Willingness of adoption are independent.

H1: Type of farmers and their Willingness of adoption are dependent.

\section{Water productivity}

In order to evaluate this technology in the farmers field trail will conducted 45 location (farmers field) as 15 sprinkler irrigation, 15 border irrigation and 15 flood irrigation as control. Presented in table the average water productivity in case of sprinkler irrigation system as border irrigation system and flood irrigation system was found $1.27 \mathrm{~kg} / \mathrm{m}^{3}, 0.74$ $\mathrm{kg} / \mathrm{m}^{3}$ and $0.67 \mathrm{~kg} / \mathrm{m}^{3}$ respectively (Fig. 3).

It can be concluded from the study that shifting to pressurized irrigation in commands area of Samrat Ashok Sagarmejor irrigation project is feasible both from technical and financial point of view. The system reduced the turbidity of the water and provided continuous supply of water so that pressurized irrigation systems can be used with the canal irrigation system. In this found that sprinkler irrigation system must be adopted in the command area was increase in the water productivity. $71.62 \%$ increase was observe in water productivity was found if border irrigation system is replace by sprinkler irrigation system. Similarly $89.55 \%$ increase in water productivity was found if flood irrigation system is replace by sprinkler irrigation system, bout $11 \%$ increase in water productivity was found if flood irrigation system is replaced by border irrigation system.

\section{Acknowledgments}

I would like to extend sincere thanks to my adviser, Dr. S.K. Pyasi, for the knowledge, guidance and freedom. He provided throughout the course of this project.

\section{References}

Anonymous, 2015. Agricoop annual report, Government of India.

Navalwala, B, N., 1991. Waterlogging and its 
related issues in India. J Irrigation and Power, 55-64.

Nema, R. K., and Shrivastava, R. N. 2012.Pressurized Irrigation in Canal Command Area. Proceeding of National Seminar on Modernization and Monitoring of Irrigated Command held at CAE, JNKVV 21-22 Nov. p-11.

Rathod, S. A., and Shah, S. D. 2013. TecnoEconomic Feasibility of Pressurized Irrigation System in Canal Commands A Case Study. Global Research
Analysis (2): 68-73.

Shrivastava, R. C., Mohanty, S., Singandhuppe, R. B., Mohanty, R. K., Behera, M. S., Ray, L. P., and Sahoo, D. 2010 Feasibility Evaluation of Pressurized Irrigation in Canal Commands. Water Resource Manage 24:3017-3032.

Zardari, N. H., and Cordery, I. 2009.Water productivity in a rigid irrigation delivery system. Water Resour Manage 23(6): $1025-1040$.

\section{How to cite this article:}

Shiv Singh Basediya, S.K. Pyasi, R.N. Shrivastava and Sharma, S.K. 2018. Feasibility of Pressurized Irrigation in Canal Command Area of Samrat Ashok Sagar Project a Case Study. Int.J.Curr.Microbiol.App.Sci. 7(02): 1540-1546. doi: https://doi.org/10.20546/ijcmas.2018.702.185 